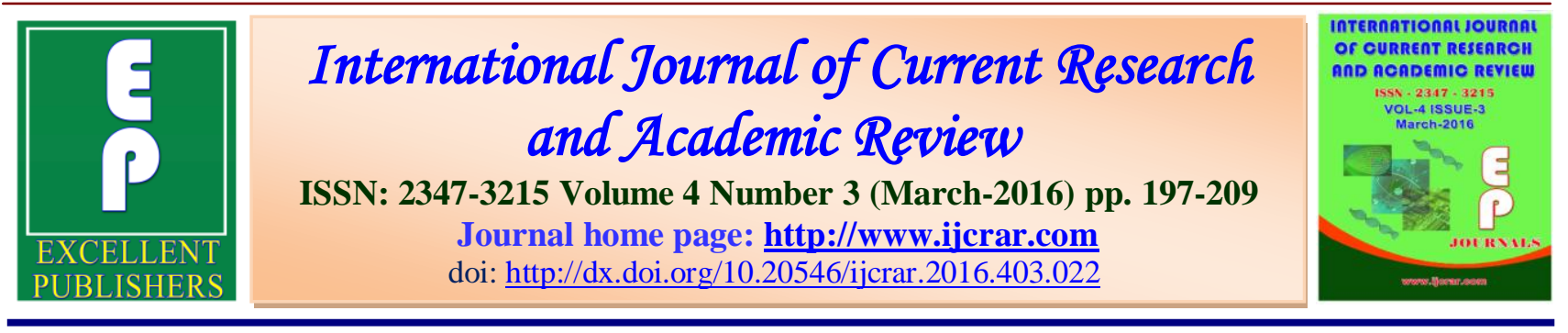

\title{
The Associations between Lifestyles, Clinical and Urinary Biochemical Indicators of Nutrition and Health among men living in a peri-urban community in Accra, Ghana
}

\author{
Frederick Vuvor $^{1 *}$, Matilda Steiner-Asiedu ${ }^{1}$, Kwesi Firibu Saalia ${ }^{1}$ and \\ William Bruce Owusu ${ }^{1}$
}

Department of Nutrition and Food Science, School of Biological Sciences, College of Basic and Applied Sciences, University of Ghana

*Corresponding author

\begin{tabular}{|c|c|}
\hline KEYWORDS & A B S T R A C T \\
\hline $\begin{array}{l}\text { Urinary } \\
\text { leukocyte, } \\
\text { Prostate } \\
\text { hypertrophy, } \\
\text { UTI }\end{array}$ & $\begin{array}{l}\text { As a result of unhealthy lifestyles of men there was rise in noncommunicable } \\
\text { diseases in many developing countries like Ghana. There is little focus on } \\
\text { men and members living in peri-urban communities in terms of nutrition and } \\
\text { health studies. There is increased stress on members due to instability, } \\
\text { migration from rural and addiction to tobacco and alcohol use especially } \\
\text { among men. Therefore this study was conducted to critically examine the } \\
\text { health of adult men in peri urban community. The study was a cross-sectional } \\
\text { covering socio-demographic, lifestyle, dietary intakes, anthropometry, } \\
\text { clinical and biochemical assessments of men. The census yielded } 207 \text { who } \\
\text { were willing to participate in the study. The average age of the respondents } \\
\text { was } 40 \pm 14.3 \text { ranging from } 19 \text { to } 95 \text { years. About } 71.0 \% \text { consumed alcohol } \\
\text { and } 22.2 \% \text { smoked tobacco. Only } 43.5 \% \text { of the study population met their } \\
\text { overall nutrient needs. The mean height of the men was } 1.70 \pm 0.07 \text { ranging } \\
\text { from } 1.6 \text { to1.9metres. The mean weight and BMI were } 65.91 \pm 1.04 \mathrm{~kg} \text { and } \\
22.85 \pm 3.15 \mathrm{~kg} / \mathrm{m} 2 \text { respectively. About } 7.2 \% \text { of the men were underweight } \\
\text { (<18.5kg/m2) while } 24.6 \% \text { were overweight }>25 \mathrm{~kg} / \mathrm{m} 2 \text {. Many of them } \\
\text { suffered from ailments such as body pains (60.4\%), headache (52.2\%), } \\
\text { abdominal disturbances ( } 41.5 \%) \text {, URI ( } 43.5 \%) \text { and others. One of the risk } \\
\text { factors of urinary leukocyte excretion in this study was abdominal } \\
\text { disturbances (OR: } 4.00,95 \% \text { Cl: } 2.07-7.42) \text {. Lifestyle factors such as } \\
\text { smoking, excessive alcohol consumption, obesity and lack of physical } \\
\text { activity may jointly affect co-morbidities such as idiopathic urinary leukocyte } \\
\text { excretion and vice versa. Clinical and biochemical diagnoses could also } \\
\text { synergistically effect morbidity of men. Health education regarding quitting } \\
\text { addiction of smoking and moderation in alcohol consumption as well as } \\
\text { regular medical checkup especially annual examination of PSA should be } \\
\text { advisable. }\end{array}$ \\
\hline
\end{tabular}




\section{Introduction}

To maintain good health, it is important that daily foods are eaten from three main food groups specifically: energy given foods (cereals, starchy fruits, roots and tubers, oils and fat), body building foods (animal source foods and legumes) and protective foods (fruits and vegetables) in additions to drinking enough water and engaging in healthy lifestyles (regular physical activity, limit alcohol intake and avoid tobacco use). Foods eaten however, must be in moderation, balanced, adequate and wholesome to maintain a healthy physique within the socio-economic and sociocultural context. Any derailment from these conditions can impact on health negatively.

The literature reveals that men's health and nutrition studies are not major concerns for most researchers. However, men are known to have higher mortality rate and shorter life span (Lynch 2013; Wang et al. 2013; White and Holmes 2006; White et al. 2013; Wang et al. 2010). In Ghana, life expectancy at birth is 63.38 years for men and 66.19 for women (GSS and Macro 2009). Globally, 'the millennium development goals (MDGs), post-2015 global development agenda (Poverty 2015; Awortwi 2012; $<$ Trends in consultation rates in general practice 1995 to 2006.pdf> ; Economic 2008)and Ghana Demographic and Health Survey' (GDHS) (Service et al. 2004; Demographic ; GSS and Macro 2009) were research agenda basically set for women and children. From another dimension, relatively little focus has been placed on peri-urban communities, in terms of research. It has been noted also that peri-urban areas might to be nutritionally and socio-economically worse off than either urban or rural areas (Maxwell et al. 2000).

Excessive alcohol consumption has been found to be responsible for between 88,000 and 2.5 million deaths each year in the United States (McKnight-Eily et al. 2014). Smoking account for some of the malefemale differences in mortality. The disease that contribute most to the widening mortality gap between the two sexes are linked to lifestyle differences. It is known in almost all populations studiesthat, more men than women smoke and that, among smokers, men tend to have more harmful smoking habits than women (Lundberg et al. 2007; Stafford and McCarthy 2006).

Health-risk behaviours such as low physical activity contributes to the prediction of reduced health-related quality of life. This has been demonstrated repeatedly in many studies for low physical activity (Ford et al. 2001; Hassan et al. 2003; Heath and Brown 2009; Herman et al. 2012; Jia and Lubetkin 2005; Kruger et al. 2007; Larsson et al. 2002; Yancy et al. 2002; van Grieken et al. 2013). Studies have also indicated that higher levels of physical activity were associated with a reduced rate of all-cause mortality. Plausibly changes in patterns of physical activity over time influence mortality (Leon et al. 1987; Paffenbarger Jr et al. 1993; Slattery and Jacobs 1988).

There is therefore the need to understand the critical health and nutrition related issues on men. There is also an obvious knowledge gap that need to be closely studied in periurban communities. This article summarizes the key findings from thisstudy. It is hoped these findings will serve as some of the essential steps toward identifying and addressing gaps in men's health.

\section{Materials and Methods}

The study was a community-based crosssectional case-study involving adult men. The study covered men's general health, socio-demographic (age, level of formal education, socioeconomic status, and marital 
status), lifestyle (alcohol use, tobacco use and physical activity), dietary data (diet history method), anthropometry (height and weight), clinical andbiochemical assessments.

The census yieldeda total of 1023 men $\geq 18$ years of age living in the whole community in Ghana out of which 207consented to participate and were recruited into the study.They were assured of strict confidentiality of any information obtained from them. The data were collected using pre-designed, pre-tested WHO Step-wise and modified questionnaire.Written informed consent formswere administered first to theconsented men.

\section{Nutrient adequacy and Mean adequacy}

To estimate the nutrient sufficiency of the diet intake per day, a Nutrient Adequacy Ratio (NAR) and Mean nutrient Adequacy Ratio (MAR) were computed for intakeof 9 nutrients. The NAR is the nutrient intake divided by the Recommended Dietary Allowance (RDA) for each individual and expressed as a percent(Hatluy et al. 1998). RDAs are often used to compare dietary quality among population subgroups (Ries and Daehler 1986; Torheim et al. 2004; Madden et al. 1976; Guthrie and Scheer 1981). The NAR was based on the mean percentage of the recommended intakes for nutrients from all the " $n$ " different foods intake as follows:

$\mathrm{NAR}_{i}=100 / \mathrm{n} * \sum_{p=1}^{p=n}\left(\right.$ Intake $\left.{ }_{p} / \mathrm{RDA}_{p}\right)$

Where Intake $\mathrm{p}$ is the daily intake of each nutrient ${ }_{\mathrm{p}}$, (mean food intake/day) and RDA $\mathrm{p}$ is the Recommended Dietary Allowance for a day and " $n$ " is the list and reference value for the " $n$ " recommended nutrients, but in this case " $n$ " is one nutrient. $\mathrm{NAR}_{i}$ is the actual total amount of a nutrient intake per day, calculated for the whole diet.

The NAR for a given nutrient is the ratio of a subject's intake to the current recommended allowance for each age category(Hatluy et al. 1998). As an overall measure of the nutrient sufficiency, the Mean Adequacy Ratio (MAR) was also computed as described by (Madden et al. 1976). The mean of 9 NARs for calories, protein, fat, carbohydrates, iron, calcium, sodium, vitamin $B_{1}$ and vitamin $B_{12}$ consumed by each man. In this case NAR was truncate at 1 so that a nutrient with a high NAR could not compensate for a nutrient with a low NAR.

$$
\text { MAR }=\frac{\left.\sum \text { NAR(eachtruncated at } 1\right)}{\text { Numberof nutriets }}
$$

\section{Biochemical examinations}

Urine Reagent Strips (URIT 10V) was used to test freshly voided midstream urine. URIT $10 \mathrm{~V}$ urine reagent strips provide test for the semi-quantitative measurement of leukocytes, urobilinogen, bilirubin, blood, nitrite, $\mathrm{pH}$, specific gravity, protein, glucose, and ketone in urine. (The reagent is produced by URIT Medical Electronic Co. Ltd. N.o4 East Aley, Jiuhua Road, Guilin, Guangxi 541001, PR China and supply by: URIT Medical Electronic Co., Ltd. www.urit.com)

\section{Test principles}

Urine Leukocytes:The test reveals the presence of granulocyte esterases. These esterases cleave an indoxyl ester, and the indoxyl so liberated reacts with a diazonium salt to produce a violet dye. The test area does not react with lymphocyte. 
Urine Urobilinogen:This test is based on the Ehrlich reaction. This test area detects urobilinogen in concentrations as low as $3 \mu \mathrm{mol} / \mathrm{L}$ (approximately $0.2 \mathrm{Ehrlich}$ unit/L) in urine.

Urine Bilirubin:This test is based on the coupling of bilirubin with diazonium salt in an acid medium. Normally no bilirubin is detectable in urine by even the most sensitive methods. Even trace amounts of bilirubin are sufficiently abnormal to require further investigation.

Urine Blood:Hemoglobin and myoglobin catalyze the oxidation of the indication of the indicator by means of organic hydroperoxide contained in the test paper. The test is equally sensitive to myoglobin as to hemoglobin (Hemoglobin concentration of $150 \mu \mathrm{g} / \mathrm{L}-620 \mu \mathrm{g} / \mathrm{L}$ is approximately equivalent to 5-15 intact red blood cells per microlitre).

Urine Nitrite:The test is based on the principle of Griess's test and is specific to nitrite. Any degree of uniform pink colour development should be interpreted as a positive. Nitrite test suggesting the presence of $10^{5}$ or more organisms per $\mathrm{mL}$.

Urine pH:This test contains a mixed indicator which assures a marked change in colour between $\mathrm{pH} 5$ and $\mathrm{pH} 8.5$

Urine specific gravity: This test contains a detergent a bromthymol blue that indicates the presence of ionic constituents in the urine by changing colour from green to yellow. The specific gravity test permits determination of urine specific gravity between 1.000 and 1.030 .

Urine protein: The test is based on the principle of the protein error of a $\mathrm{pH}$ indicator. The reagent area is more sensitive to albumin.

Urine glucose: The test is based on the specific glucose oxidase/peroxidase reaction. The test is specific for glucose, no substance excreted in urine other than glucose is known to give a positive result.

Urine ketone: This test is based on the principle of Legal's test and is more sensitive to acetoacetic than to acetone. The reagent does not react with $\beta$ hydroxybutyric acid.

\section{Test procedure}

A specimen of freshly voided midstream urine was collected. The reagent areas of the test strip was immersed and removed immediately. Each reagent area was compared to its corresponding color blocks, shown on the color chart and read.

\section{Sensitivity and ranges of Urinalysis of diagnostic tool}

Leukocytes: Sensitivity: (15-40) cells/ $\mu \mathrm{L}$ granulocyte; Ranges: (15-500) cells $/ \mu \mathrm{L}$; normal values: 0

Urobilinogen: Sensitivity: (3.3-16) $\mu \mathrm{mol} / \mathrm{L}$;Ranges: (33- $\geq 131) \mu \mathrm{mol} / \mathrm{L}$; normal values: 0

Bilirubin: $\quad$ Sensitivity: (3.4-8.6) $\mu \mathrm{mol} / \mathrm{L} ;$ Ranges: (8.6-100) $\mu \mathrm{mol} / \mathrm{L}$; normal level: 0

Blood: Sensitivity: (0.3-0.6) $\mathrm{mg} / \mathrm{L}$ hemoglobin; Ranges: $(10-\geq 200)$ cells $/ \mu \mathrm{L}$; normal values:0

Nitrite: Sensitivity: $\quad(13-22) \quad \mu \mathrm{mol} / \mathrm{L}$; Ranges: Negative; normal values:0 
pH: Sensitivity: 0-5pH unit; normal values: $\mathrm{pH}$ 5.0-8.5

Specific Gravity: Sensitivity: Between 1.000 to 1.035 ; normal values: $1.000-1.030$

Protein: Sensitivity: (0.10-0.15) g/L albumin; Ranges: $(0.15 \geq 5.0) \mathrm{g} / \mathrm{L}$; normal values: 0

Glucose: Sensitivity: (2.8-5.5) $\mathrm{mmol} / \mathrm{L}$; Ranges: (2.8-110) mmol/L; normal values: 0 .

Ketone: Sensitivity: (0.3-0.5) $\mathrm{mmol} / \mathrm{L}$; Ranges: (0.5-16.0) mmol/L; normal values: 0 .

Sources: (Urinalysis 2005; Buchsbaum et al. 2004; Messing et al. 1987; Scheer 1987; Shaw et al. 1985).

\section{Statistical analyses}

Data entry and management system was designed using SPSS version 16 (SPSS Inc, Chicago, IL). ESHA Food Processor (ESHA Research, 2012w, 4747 Skyline Rd s, Suite 100, Salem. OR 97306 USA) and MS Excel 2013 (Microsoft Corp, Redmond, WA) soft wares were used to analyze the dietary data. Descriptive statistics (frequencies, mean, standard deviations, and ranges) were calculated for continuous variables and proportions for qualitative variables. To assess the risk and association between outcome and independent variables, binary logistic regression analysis was carried out.

\section{Results and Discussion}

The average age of the respondents was $40 \pm 14.3$ ranging from 19 to 95 years. About sixty-nine percent $(68.6 \%)$ of the respondents were married. The majority $(75.3 \%)$ of the men were selfemployed.More than three-fourth $(71.0 \%)$ were alcohol user and an appreciable proportion $(22.2 \%)$ of them smoked tobacco (Table 1).

Irrespective of age differences, the study participants mostly patronized street foods as their breakfast and lunch, only $27.5 \%$ and $24.6 \%$ took their breakfast and lunch at home respectively. Evening meal was the one that majority $(82.6 \%)$ ate at home. The significant difference in their food intakes lied in the cereal/grain, the starchy root/tuber and the legumes/oil seed/nuts only. About $\geq 60 \%$ of the study population depended largely on cereal food as $\leq 20 \%$ of the participants consumed legume/oilseed/nut products (Table 2).

The nutrients intakes of the men were compared to their respective Recommended Dietary Allowance (RDA). It was indicated that the majority of men fell below the cutoff of $60 \%$ of their RDA (WHO/FAO, 2011) of all the nutrients intake except iron $(84.1 \%)$ and protein $(54.6 \%)$. About $50 \%$ of men aged above 60 years met their caloric intake. Fifty percent of all men aged above 51 years score $\geq 60 \%$ of their overall nutrients needs. Only $43.5 \%$ of the study population score $\geq 60 \%$ of their overall nutrients needs (Table 3 ).

The mean height of the men was $1.70 \pm 0.07$ metres, ranging from 1.6 to 1.9 metres. The mean weight and BMI were $65.91 \pm 1.04 \mathrm{~kg}$ and $22.85 \pm 3.15 \mathrm{~kg} / \mathrm{m}^{2}$ respectively. About $7.2 \%$ of the men were underweight $\left(<18.5 \mathrm{~kg} / \mathrm{m}^{2}\right) \quad$ while $24.6 \%$ were overweight $>25 \mathrm{~kg} / \mathrm{m}^{2}$. The health history of the participants revealed interesting information. When the participants were asked to evaluate their own health, majority $(82.6 \%)$ claimed that they were in good health. However, the medical histories and physical examinations presented contrary information which revealed that many of 
them suffered and some continued suffering from various ailments such as body pains $(60.4 \%)$, headache $(52.2 \%)$, abdominal disturbances $(41.5 \%)$, urinary tract infection (URI) $(43.5 \%)$ and others. The urine chemistries were also evaluated since the biomarkers give a true reflection of individual's nutrition and health situation. Urine examinations indicated that about a third $(29 \%)$ of the men had leukocytes in their urine (Table 4).

Regression analyses shows that socioeconomic status (OR: $8.33,95 \% \mathrm{Cl}$ : 2.27-25), physical activity scores (OR: 0.30, 95\% Cl: 0.16-0.57), and abdominal disturbances (OR: 4.00, 95\% Cl: 2.07-7.42), had significant association with excreting urinary leukocytes (Table 5).

Self-rated health is a strong predictor of disease and mortality which is a valid proxy for the current health status of any individual (DeSalvo et al. 2009; Idler and Benyamini 1997; Møller et al. 1996; DeSalvo et al. 2006), however, this study has shown conflicting accounts, as the participants in this study self-rated their health status rather contrary to clinical and biochemical examinations.

Urine analyses revealed that about $29 \%$ of the participants had leukocytes in their urine. This clearly showed that there was leakages through the endothelial membrane of any part of the urinary tracts (from kidneys to penile urethra). The greatest suspicious part was the prostatic urethra as a result of a benign prostatic hypertrophy which is known to affect men usually above 40 years of age. If it were the enlargement of the prostate gland then the well thought out by the medical community for men to do Prostate Specific Antigen (PSA) examination yearly at the age of $\geq 40$ years could be looked at again. This study has revealed that as young as 18-30 years old men were having leukocytes in their urine. Leukocytes in urine is aninsidious sign that one is suffering from an infection or a damage in any part of the renal system. Damage to the kidneys (nephrons), ureters, bladder or urethra can cause leukocytes to appear. This can also be triggered when foreign materials (organic or inorganic) are found in the body. A blockage in the urinary tract can also cause leukocytes to appear in the urine. Trauma to the pelvis, or prostate hypertrophy can cause a blockage that damages the endothelial membrane of the urinary system. A UTI is a common cause of leukocytes in urine. In men, infection may start in the prostate and move up into the bladder, causing cystitis (Urinalysis 2005).It is abnormal to have leukocytes in urine of intact urinary system without any injury in the kidneys, ureters, bladder or urethra (Feld et al. 1997; Patel and Bissler 2001; Reine and Langston 2005; Haylen et al. 2010).

In the regression analysis low physical activity appeared to be protective of urinary leukocyte excretion (OR: 0.30, 95\%Cl: 0.160.57). This may be because retention of urine in the urinary bladder is known to be one of the causes of excreting leukocyte. Physiologically too much retention of urine which is common with many physically active people might show in the risk assessment of urinary excretion of leukocytes. One of the risk factors of urinary leukocyte excretion in this study was abdominal disturbances (OR: 4.00, 95\% Cl: 2.07-7.42). Anatomically the whole of the kidneys are abdominal organs and more than two-third of the urinary bladder is in the abdominal cavity. Therefore any disorder affecting the kidneys or any parts of the urinary bladder could be felt as abdominal disturbance. Therefore the binary regression analyses could be justified for labeling abdominal disturbances as a risk factor for urinary leukocyte excretion. 
Int.J.Curr.Res.Aca.Rev.2016; 4(3): 197-209

Table.1 Background characteristics of the Participants (N=207)

\begin{tabular}{|c|c|c|c|c|c|c|}
\hline \multirow{2}{*}{ Variable } & \multicolumn{6}{|c|}{${ }^{1}$ Age $\{$ Years; $\mathbf{n}(\%)\}$} \\
\hline & $18-30$ & $31-40$ & $41-50$ & $51-60$ & $>60$ & Total n(\%) \\
\hline \multicolumn{7}{|l|}{ Education } \\
\hline$<\mathrm{SHS}$ & $\begin{array}{l}29 \\
(54.7)\end{array}$ & $42(68.9)$ & $36(80)$ & $21(70)$ & $9(50)$ & $137(66.2)$ \\
\hline$=>$ SHS & $\begin{array}{l}24 \\
(45.3)\end{array}$ & 19(31.1) & $9(20.0)$ & 9(30) & $9(50)$ & $70(33.8)$ \\
\hline \multicolumn{7}{|c|}{ Marital status } \\
\hline Married & $\begin{array}{l}12 \\
(22.6)\end{array}$ & $55(90.2)$ & $39(86.7)$ & $18(60)$ & $18(100)$ & $142(68.6)$ \\
\hline${ }^{2}$ Single & $\begin{array}{l}41 \\
(77.4)\end{array}$ & $6(9.8)$ & $6(20)$ & $12(40)$ & 0 & $65(31.4)$ \\
\hline \multicolumn{7}{|l|}{ Alcohol use } \\
\hline Users & $26(49.1)$ & $46(75.4)$ & $36(80)$ & $27(90)$ & $\begin{array}{l}12 \\
(66.7)\end{array}$ & 147(71.0) \\
\hline \multicolumn{7}{|l|}{ Tobacco user } \\
\hline Users & $3(5.7)$ & $10(16.4)$ & $6(13.3)$ & $18(60)$ & $9(50)$ & $46(22.3)$ \\
\hline \multicolumn{7}{|c|}{ Socioeconomic Score } \\
\hline Low & $9(17)$ & $18(29.5)$ & $21(46.7)$ & $12(30)$ & $6(33.3)$ & $66(31.9)$ \\
\hline Middle & $44(83)$ & $43(70.5)$ & $21(46.7)$ & $18(60)$ & $12(66.7)$ & $138(66.7)$ \\
\hline Upper & 0 & 0 & $3(6.7)$ & 0 & 0 & 3(1.4) \\
\hline \multicolumn{7}{|c|}{$\begin{array}{l}\text { Physical Activity } \\
\text { Score }\end{array}$} \\
\hline Inactive & $6(11.3)$ & $12(19.7)$ & $18(40)$ & $6(20)$ & $3(16.7)$ & $45(31.9)$ \\
\hline Moderate & $35(66)$ & $37(60.7)$ & $21(46.7)$ & $21(70)$ & $15(83.3)$ & $129(66.7)$ \\
\hline Active & $12(22.6)$ & $12(19.7)$ & $6(13.3)$ & $3(10)$ & 0 & $33(1.4)$ \\
\hline \multicolumn{7}{|l|}{ Occupation } \\
\hline Unemployed & $3(5.7)$ & 0 & $3(6.7)$ & $3(10)$ & $3(16.7)$ & $12(10.1)$ \\
\hline Artisan & $27(50.9)$ & $36(59)$ & $18(40)$ & $3(10)$ & $3(16.7)$ & $87(42)$ \\
\hline Salary job & $9(17)$ & $13(21.3)$ & $9(20)$ & $3(10)$ & $6(33.3)$ & $40(19.3)$ \\
\hline Casual labour & $14(26.4)$ & $6(9.8)$ & $6(13.3)$ & $9(30)$ & 0 & $35(16.9)$ \\
\hline Farm/fishing & 0 & $6(9.8)$ & $9(20)$ & $12(40)$ & $6(33.3)$ & $33(15.9)$ \\
\hline \multicolumn{7}{|c|}{$\begin{array}{l}\text { Monthly income } \\
\text { (USD) }\end{array}$} \\
\hline$<25$ & $3(5.7)$ & $3(4.9)$ & $6(13.3)$ & $3(10)$ & $6(33.3)$ & $21(10.1)$ \\
\hline $25<75$ & $3(5.7)$ & $6(9.8)$ & $3(6.7)$ & $3(10)$ & $3(16.7)$ & $18(8.7)$ \\
\hline $75<125$ & $9(17)$ & $10(16.4)$ & $3(6.7)$ & $3(10)$ & $3(16.7)$ & $28(13.5)$ \\
\hline $125<250$ & $12(22.6)$ & $12(19.7)$ & $12(26.7)$ & $9(30)$ & 0 & $45(21.7)$ \\
\hline $250<625$ & $12(22.6)$ & $18(29.5)$ & $12(26.7)$ & $3(10)$ & $3(16.7)$ & $48(23.2)$ \\
\hline$\geq 625$ & $14(26.4)$ & $12(19.7)$ & $9(20)$ & $9(30)$ & $3(16.7)$ & $47(2.7)$ \\
\hline
\end{tabular}

${ }^{1}$ Age in completed years; ${ }^{2}$ Single $=$ unmarried, divorced, separated, widowed. 
Int.J.Curr.Res.Aca.Rev.2016; 4(3): 197-209

Table.2 Foods eaten at home and away from home $(\mathrm{N}=207)$

\begin{tabular}{|c|c|c|c|c|c|c|c|}
\hline \multirow[t]{2}{*}{ Variable } & & \multicolumn{6}{|c|}{${ }^{1}$ Age $\{$ Years; n (\%)\} } \\
\hline & & 18-30 & 31-40 & 41-50 & 51-60 & $>60$ & Total n(\%) \\
\hline \multicolumn{8}{|c|}{ Breakfast meal per age per food groups } \\
\hline \multirow{2}{*}{ Cereal/grain } & Home & $9(17)$ & $6(9.8)$ & $6(13.3)$ & $9(30)$ & $3(16.7)$ & 33(15.9) \\
\hline & Away & $32(60.3)$ & $36(59)$ & $18(40)$ & $15(50)$ & $6(33.3)$ & $\mathbf{1 0 7}(51.7)$ \\
\hline \multirow[t]{2}{*}{ Starchy root/tuber } & Home & $0(0)$ & $7(11.5)$ & $3(6.7)$ & $0(0)$ & $3(16.7)$ & $\mathbf{1 3}(6.3)$ \\
\hline & Away & $3(5.7)$ & $9(14.8)$ & $18(40)$ & $3(10)$ & $9(50)$ & 39(18.8) \\
\hline \multirow[t]{2}{*}{ Legume/Oil seed/Nut n } & Home & $9(17)$ & $3(4.9)$ & $0(0)$ & $0(0)$ & $0(0)$ & 12(5.8) \\
\hline & Away & $0(0)$ & $0(0)$ & $0(0)$ & $3(10)$ & $0(0)$ & 3(1.4) \\
\hline \multicolumn{8}{|c|}{ Lunch meal per age per food groups } \\
\hline \multirow[t]{2}{*}{ Cereal/grain } & Home & $6(11.3)$ & $3(4.9)$ & $12(26.7)$ & $9(30)$ & $0(0)$ & 30(14.5) \\
\hline & Away & $35(66)$ & $39(63.9)$ & $12(26.7)$ & $15(50)$ & $9(50)$ & 110(53.1) \\
\hline \multirow[t]{2}{*}{ Starchy root/tuber } & Home & $0(0)$ & $7(11.5)$ & $9(20)$ & $3(10)$ & $0(0)$ & 19(9.2) \\
\hline & Away & $3(6.7)$ & $9(14.8)$ & $12(26.7)$ & $0(0)$ & $9(50)$ & 33(15.9) \\
\hline \multirow[t]{2}{*}{ Legume/Oil seed/Nut n } & Home & $3(6.7)$ & $0(0)$ & $0(0)$ & $0(0)$ & $0(0)$ & $3(1.4)$ \\
\hline & Away & $6(11.3)$ & $3(4.9)$ & $0(0)$ & $3(10)$ & $0(0)$ & 12(5.8) \\
\hline \multicolumn{8}{|c|}{ Supper meal per age per food groups } \\
\hline \multirow[t]{2}{*}{ Cereal/grain } & Home & $24(45.3)$ & $42(68.9)$ & $21(46.7)$ & $18(60)$ & $9(50)$ & 114(55.1) \\
\hline & Away & $17(32.1)$ & $0(0)$ & $3(6.7)$ & $6(20)$ & $0(0)$ & 26(12.6) \\
\hline \multirow[t]{2}{*}{ Starchy root/tuber/ fruit } & Home & $3(6.7)$ & $16(26.2)$ & $12(26.7)$ & $3(10)$ & $9(50)$ & $\mathbf{4 3}(20.8)$ \\
\hline & Away & $0(0)$ & $0(0)$ & $9(20)$ & $0(0)$ & $0(0)$ & $9(4.3)$ \\
\hline \multirow[t]{2}{*}{ Legume/Oil seed/Nut n } & Home & $9(17)$ & $3(4.9)$ & $0(0)$ & $3(10)$ & $0(0)$ & $\mathbf{1 5}(7.2)$ \\
\hline & Away & $0(0)$ & $0(0)$ & $0(0)$ & $0(0)$ & $0(0)$ & $\mathbf{0}(0)$ \\
\hline
\end{tabular}

Table.3 Sufficiency Nutrients Intake (N=207)

\begin{tabular}{|l|l|l|l|l|l|l|}
\hline Variable & \multicolumn{7}{l}{ Age $\{$ Years; $(\%)\}$} \\
\hline & $\mathbf{1 8 - 3 0}$ & $\mathbf{3 1 - 4 0}$ & $\mathbf{4 1 - 5 0}$ & $\mathbf{5 1 - 6 0}$ & $>\mathbf{6 0}$ & Total n(\%) \\
\hline *NAR $\geq \mathbf{6 0 \%}$ & & & & & & \\
\hline Calories & $9(17)$ & $9(14.8)$ & $6(13.3)$ & $6(20)$ & $9(50)$ & $\mathbf{3 9}(24.3)$ \\
\hline Protein & $29(54.7)$ & $36(59)$ & $21(46.7)$ & $18(60)$ & $9(50)$ & $\mathbf{1 1 3}(54.6)$ \\
\hline Fat & $12(22.6)$ & $15(24.6)$ & $12(26.7)$ & $9(30)$ & $9(50)$ & $\mathbf{5 7}(27.5)$ \\
\hline Carbohydrate & $12(22.6)$ & $12(19.7)$ & $9(20)$ & $9(30)$ & $9(50)$ & $\mathbf{5 1}(24.6)$ \\
\hline Dietary Iron & $50(94.3)$ & $52(85.2)$ & $33(73.3)$ & $24(80)$ & $15(83.3)$ & $\mathbf{1 7 4}(84.1)$ \\
\hline Dietary Calcium & $29(54.7)$ & $24(39.3)$ & $30(66.7)$ & $12(40)$ & $6(33.3)$ & $\mathbf{1 0 1}(48.8)$ \\
\hline Dietary Sodium & $9(17)$ & $15(24.6)$ & $9(20)$ & $12(40)$ & $12(66.7)$ & $\mathbf{5 7}(27.5)$ \\
\hline Vitamin B ${ }_{1}$ & $9(17)$ & $18(29.5)$ & $9(20)$ & $6(20)$ & $3(16.7)$ & $\mathbf{4 5}(21.7)$ \\
\hline Vitamin B ${ }_{12}$ & $3(5.7)$ & $9(14.8)$ & $3(6.6)$ & $12(40)$ & $3(16.7)$ & $\mathbf{3 0}(14.5)$ \\
\hline${ }^{1}$ MAR $\geq \mathbf{6 0 \%}$ & $24(45.3)$ & $21(34.4)$ & $21(46.7)$ & $15(50)$ & $9(50)$ & $\mathbf{9 0}(43.5)$ \\
\hline
\end{tabular}

"NAR $=\mathrm{X} / \mathrm{RDA} \times 100$. Where $\mathrm{X}=$ weight of dietary nutrient and RDA= Recommended Dietary Allowance of all nutrients

${ }^{1}$ MAR=Mean of all the 9 NARs each truncated at 1 
Int.J.Curr.Res.Aca.Rev.2016; 4(3): 197-209

Table.4 Anthropometric, Medical History and Clinical Indices (N=207)

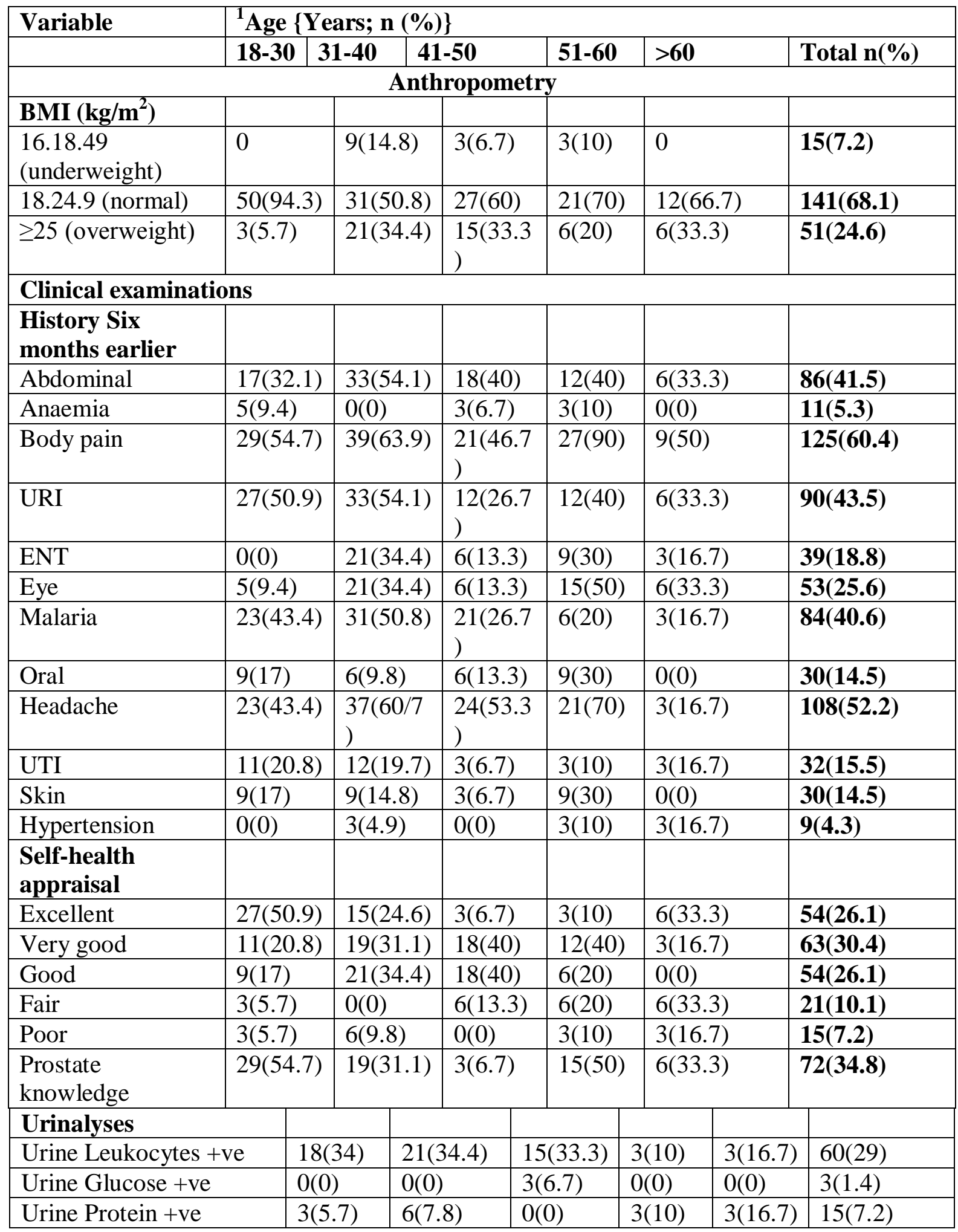


Int.J.Curr.Res.Aca.Rev.2016; 4(3): 197-209

Table.5 Binary Regression for Urinary Leukocytes

\begin{tabular}{|c|c|c|c|c|c|c|c|}
\hline \multirow[b]{2}{*}{ Variable } & \multicolumn{4}{|c|}{ Unadjusted } & \multicolumn{3}{|c|}{${ }^{1}$ Adjusted } \\
\hline & $\mathbf{n}$ & Odds Ratio & $95 \% \mathrm{Cl}$ & P-value & Odds Ratio & $95 \% \mathrm{Cl}$ & P-value \\
\hline $\begin{array}{c}\text { Age } \\
>40 \\
\leq 40 \\
\end{array}$ & $\begin{array}{c}93 \\
114 \\
\end{array}$ & $\begin{array}{l}0.56 \\
1.00 \\
\end{array}$ & $\begin{array}{c}0.30-1.00 \\
\text { Ref }\end{array}$ & 0.07 & & & \\
\hline $\begin{array}{c}\text { Education } \\
<\mathrm{SHS} \\
\geq \mathrm{SHS}\end{array}$ & $\begin{array}{c}137 \\
70\end{array}$ & $\begin{array}{l}1.46 \\
1.00\end{array}$ & $\begin{array}{c}0.79-2.73 \\
\text { Ref }\end{array}$ & 0.23 & $\begin{array}{l}1.40 \\
1.00\end{array}$ & $\begin{array}{c}0.74-2.62 \\
\text { Ref }\end{array}$ & 0.30 \\
\hline $\begin{array}{c}\text { Marital } \\
\text { Married } \\
\text { Single } \\
\end{array}$ & $\begin{array}{c}142 \\
65 \\
\end{array}$ & $\begin{array}{l}0.91 \\
1.00 \\
\end{array}$ & $\begin{array}{c}0.48-1.75 \\
\text { Ref }\end{array}$ & 0.78 & $\begin{array}{l}0.78 \\
1.00 \\
\end{array}$ & $\begin{array}{c}0.40-1.53 \\
\text { Ref }\end{array}$ & 0.47 \\
\hline $\begin{array}{l}\text { Alcohol } \\
\text { Yes } \\
\text { No }\end{array}$ & $\begin{array}{c}147 \\
60\end{array}$ & $\begin{array}{l}0.93 \\
1.00\end{array}$ & $\begin{array}{c}0.48-1.80 \\
\text { Ref }\end{array}$ & 0.84 & $\begin{array}{l}1.05 \\
1.00\end{array}$ & $\begin{array}{c}0.54-2.07 \\
\text { Ref }\end{array}$ & 0.88 \\
\hline $\begin{array}{c}\text { Tobacco } \\
\text { Yes } \\
\text { No }\end{array}$ & $\begin{array}{c}46 \\
161\end{array}$ & $\begin{array}{l}0.53 \\
1.00\end{array}$ & $\begin{array}{c}0.24-1.17 \\
\text { Ref }\end{array}$ & 0.11 & $\begin{array}{l}0.62 \\
1.00\end{array}$ & $\begin{array}{c}0.27-1.14 \\
\text { Ref }\end{array}$ & 0.25 \\
\hline $\begin{array}{c}\text { SES } \\
\text { Low } \\
\text { Middle }\end{array}$ & $\begin{array}{c}168 \\
39 \\
\end{array}$ & $\begin{array}{l}6.25 \\
1.00 \\
\end{array}$ & $\begin{array}{c}1.81-20.00 \\
\text { Ref }\end{array}$ & $<0.01$ & $\begin{array}{l}8.33 \\
1.00 \\
\end{array}$ & $\begin{array}{c}2.27-25 \\
\text { Ref }\end{array}$ & $<0.01$ \\
\hline $\begin{array}{l}\text { PAS } \\
\text { Low } \\
\text { High }\end{array}$ & $\begin{array}{c}86 \\
121\end{array}$ & $\begin{array}{l}0.34 \\
1.00\end{array}$ & $\begin{array}{c}0.19-0.64 \\
\text { Ref }\end{array}$ & $<0.01$ & $\begin{array}{l}0.30 \\
1.00\end{array}$ & $\begin{array}{c}0.16-0.57 \\
\text { Ref }\end{array}$ & $<0.01$ \\
\hline $\begin{array}{c}\text { BMI } \\
\geq 25 \mathrm{~kg} / \mathrm{m}^{2} \\
<25 \mathrm{~kg} / \mathrm{m}^{2} \\
\end{array}$ & $\begin{array}{c}51 \\
156 \\
\end{array}$ & $\begin{array}{l}0.69 \\
1.00 \\
\end{array}$ & $\begin{array}{c}0.33-1.44 \\
\text { Ref }\end{array}$ & 0.32 & $\begin{array}{l}0.73 \\
1.00 \\
\end{array}$ & $\begin{array}{c}0.35-1.53 \\
\text { Ref }\end{array}$ & 0.40 \\
\hline $\begin{array}{c}{ }^{2} \text { ABD-Pain } \\
+V E \\
-V E\end{array}$ & $\begin{array}{c}86 \\
121 \\
\end{array}$ & $\begin{array}{c}4.0 \\
1.00 \\
\end{array}$ & $\begin{array}{c}2.10-7.45 \\
\text { Ref }\end{array}$ & $<0.01$ & $\begin{array}{l}4.00 \\
1.00 \\
\end{array}$ & $\begin{array}{c}2.07-7.42 \\
\text { Ref }\end{array}$ & $<0.01$ \\
\hline
\end{tabular}

${ }^{\mathrm{T}}$ The multivariate logistic regression analyses model was adjusted for age and all dietary nutrients assessed.

${ }^{2} \mathrm{ABD}-\mathrm{Pain}=\mathrm{Abdominal}$ disturbances; $+\mathrm{VE}=$ presence and $-\mathrm{VE}=\mathrm{absence}$

\section{Conclusion}

Lifestyle factors such as smoking, excessive alcohol consumption, obesity and lack of physical activity may jointly affect comorbidities such as idiopathic urinary leukocyte excretion and vice versa. Clinical and biochemical diagnoses could also synergistically effect morbidity of men.Health education about regarding quitting of addiction of smoking and moderation in alcohol consumption as well as regular medical checkup especially annual examination of PSA should be advisable.

\section{Acknowledgement}

The authors acknowledge the contribution and assistance received from the study participants, chiefs, elders of the study community, all the research field assistant, the faculty academic members and the supporting staff in the Department of 
Nutrition and Food Science, School of Biological Sciences, College of Basic and Applied Sciences of the University of Ghana.

\section{References}

Awortwi, N. 2012. Post-2015 global development agenda.

Buchsbaum, G. M., D. T. Albushies, and D. S. Guzick. 2004. Utility of urine reagent strip in screening women with incontinence for urinary tract infection. International Urogynecology Journal 15 (6):391-393.

Demographic, G. Health Survey (GDHS) 2003 (2004). Ghana Statistical Service (GSS), Noguchi Memorial Institute for Medical Research (NMIMR), and ORC Macro. Calverton, Maryland: GSS, NMIMR, and ORC Macro.

DeSalvo, K. B., N. Bloser, K. Reynolds, J. He, and P. Muntner. 2006. Mortality Prediction with a Single General Self-Rated Health Question. Journal of general internal medicine 21 (3):267275.

DeSalvo, K. B., T. M. Jones, J. Peabody, J. McDonald, S. Fihn, V. Fan, J. He, and P. Muntner. 2009. Health care expenditure prediction with a single item, self-rated health measure. Medical care 47 (4):440-447.

Economic, U. N. D. o. 2008. The Millennium Development Goals Report 2008: United Nations Publications.

Feld, L. G., W. R. Waz, M. P. Luis, and D. B. Joseph. 1997. Hematuria: an integrated medical and surgical approach. Pediatric Clinics of North America 44 (5):1191-1210.

Ford, E. S., D. G. Moriarty, M. M. Zack, A. H. Mokdad, and D. P. Chapman. 2001. Self-Reported Body Mass Index and Health-Related Quality of Life: Findings from the Behavioral Risk Factor Surveillance System. Obesity Research 9 (1):21-31.
GSS, G., and I. Macro. 2009. Ghana demographic and health survey 2008. Accra, Ghana: Ghana Statistical Service, Ghana Health Service, and ICF Macro.

Guthrie, H., and J. Scheer. 1981. Validity of a dietary score for assessing nutrient adequacy. Journal of the American Dietetic Association 78 (3):240-245.

Hassan, M., A. Joshi, S. Madhavan, and M. Amonkar. 2003. Obesity and healthrelated quality of life: a cross-sectional analysis of the US population. International journal of obesity 27 (10):1227-1232.

Hatluy, A., L. Torheim, and A. Oshaug. 1998. Food varietyĐa good indicator of nutritional adequacy of the diet? A case study from an urban area in Mali, West Africa. European journal of clinical nutrition 52:891-898.

Haylen, B. T., D. De Ridder, R. M. Freeman, S. E. Swift, B. Berghmans, J. Lee, A. Monga, E. Petri, D. E. Rizk, and P. K. Sand. 2010. An International Urogynecological Association (IUGA)/International Continence Society (ICS) joint report on the terminology for female pelvic floor dysfunction. International Urogynecology Journal 21 (1):5-26.

Heath, G. W., and D. W. Brown. 2009. Recommended levels of physical activity and health-related quality of life among overweight and obese adults in the United States, 2005. Journal of physical activity \& health 6 (4):403.

Herman, K. M., W. M. Hopman, E. G. Vandenkerkhof, and M. W. Rosenberg. 2012. Physical activity, body mass index, and health-related quality of life in Canadian adults. Medicine and science in sports and exercise 44 (4):625-636.

Idler, E. L., and Y. Benyamini. 1997. Selfrated health and mortality: a review of twenty-seven community studies. Journal of health and social behavior:21-37. 
Jia, H., and E. I. Lubetkin. 2005. The impact of obesity on health-related quality-oflife in the general adult US population. Journal of public health 27 (2):156164.

Kruger, J., H. R. Bowles, D. Jones, B. E. Ainsworth, and H. r. Kohl. 2007. Health-related quality of life, BMI and physical activity among US adults (\&ges; 18 years): National Physical Activity and Weight Loss Survey, 2002. International journal of obesity 31 (2):321-327.

Larsson, U., J. Karlsson, and M. Sullivan. 2002. Impact of overweight and obesity on health-related quality of life--a Swedish population study. International journal of obesity and related metabolic disorders: journal of the International Association for the Study of Obesity 26 (3):417-424.

Leon, A. S., J. Connett, D. R. Jacobs, and R. Rauramaa. 1987. Leisure-time physical activity levels and risk of coronary heart disease and death: the Multiple Risk Factor Intervention Trial. Jama 258 (17):2388-2395.

Lundberg, I., T. Hemmingsson, and C. Hogstedt. 2007. Introductory review and background. Work and social inequalities in health in Europe 58:11.

Lynch, W. 2013. Men's health in Australia. Trends in Urology \& Men's Health 4 (1):7-10.

Madden, J. P., S. J. Goodman, and H. A. Guthrie. 1976. Validity of the 24-hr. recall. Analysis of data obtained from elderly subjects. Journal of the American Dietetic Association 68 (2):143-147.

Maxwell, D., C. Levin, M. Armar-Klemesu, M. Ruel, S. Morris, and C. Ahiadeke. 2000. Urban livelihoods and food and nutrition security in Greater Accra, Ghana: International Food Policy Research Institute Washington, DC.

McKnight-Eily, L. R., Y. Liu, R. D. Brewer, D. Kanny, H. Lu, C. H. Denny, L. Balluz, and J. Collins. 2014. Vital signs: communication between health professionals and their patients about alcohol use - 44 states and the District of Columbia, 2011. MMWR Morb Mortal Wkly Rep 63 (1):16-22.

Messing, E., T. Young, V. Hunt, S. Emoto, and J. Wehbie. 1987. The significance of asymptomatic microhematuria in men 50 or more years old: findings of a home screening study using urinary dipsticks. The Journal of urology 137 (5):919-922.

Møller, L., T. S. Kristensen, and H. Hollnagel. 1996. Self rated health as a predictor of coronary heart disease in Copenhagen, Denmark. Journal of Epidemiology and Community Health 50 (4):423-428.

Paffenbarger Jr, R. S., R. T. Hyde, A. L. Wing, I.-M. Lee, D. L. Jung, and J. B. Kampert. 1993. The association of changes in physical-activity level and other lifestyle characteristics with mortality among men. New England Journal of Medicine 328 (8):538-545.

Patel, H. P., and J. J. Bissler. 2001. Hematuria in children. Pediatric Clinics of North America 48 (6):1519-1537.

Poverty, E. 2015. Millennium development goals. United Nations. Available online: http://www. un. org/millenniumgoals/(accessed on 23 August 2011).

Reine, N. J., and C. E. Langston. 2005. Urinalysis interpretation: how to squeeze out the maximum information from a small sample. Clinical techniques in small animal practice 20 (1):2-10.

Ries, C., and J. Daehler. 1986. Evaluation of the Nutrient Guide as a dietary assessment tool. Journal of the American Dietetic Association 86 (2):228-233.

Scheer, W. D. 1987. The detection of leukocyte esterase activity in urine with a new reagent strip. American journal of clinical pathology 87 (1):86-93.

Service, G. S., N. M. I. f. M. Research, and O. M. Measure/DHS+. 2004. Ghana 
demographic and health survey, 2003: Ghana Statistical Service.

Shaw, S. T., S. Y. Poon, and E. T. Wong. 1985. 'Routine urinalysis': Is the dipstick enough? Jama 253 (11):15961600.

Slattery, M. L., and D. R. Jacobs. 1988. Physical Fitness and Cardiovascular Disease Mortality The Us Railroad Study. American Journal of epidemiology 127 (3):571-580.

Stafford, M., and M. McCarthy. 2006. Neighbourhoods, housing and health. Social determinants of health:297-317.

Torheim, L., F. Ouattara, M. Diarra, F. Thiam, I. Barikmo, A. Hatløy, and A. Oshaug. 2004. Nutrient adequacy and dietary diversity in rural Mali: association and determinants. European journal of clinical nutrition 58 (4):594-604.

Urinalysis, D. 2005. Urinalysis: a comprehensive review.

van Grieken, A., L. Veldhuis, C. M. Renders, J. M. Landgraf, R. A. Hirasing, and $\mathrm{H}$. Raat. 2013. Impaired parent-reported health-related quality of life of underweight and obese children at elementary school entry. Quality of Life Research 22 (4):917-928.

Wang, H., A. E. Schumacher, C. E. Levitz, A. H. Mokdad, and C. Murray. 2013. Left behind: widening disparities for males and females in US county life expectancy, 1985-2010. Popul Health Metr 11 (1):8.

Wang, Y., J. Tuomilehto, P. Jousilahti, R. Antikainen, M. Mähönen, P. T. Katzmarzyk, and G. Hu. 2010. Occupational, commuting, and leisuretime physical activity in relation to heart failure among finnish men and women. Journal of the American College of Cardiology 56 (14):11401148.

White, A., and M. Holmes. 2006. Patterns of mortality across 44 countries among men and women aged 15-44 years. The Journal of Men's Health \& Gender 3 (2):139-151.

White, A., M. McKee, B. de Sousa, R. de Visser, R. Hogston, S. A. Madsen, P. Makara, N. Richardson, W. Zatoński, and G. Raine. 2013. An examination of the association between premature mortality and life expectancy among men in Europe. The European Journal of Public Health:ckt076.

Yancy, W. S., M. K. Olsen, E. C. Westman, H. B. Bosworth, and D. Edelman. 2002. Relationship between Obesity and Health-Related Quality of Life in Men. Obesity Research 10 (10):1057-1064.

\section{How to cite this article:}

Frederick Vuvor, Matilda Steiner-Asiedu, Kwesi Firibu Saalia and William Bruce Owusu. 2016. The Associations between Lifestyles, Clinical and Urinary Biochemical Indicators of Nutrition and Health among men living in a peri-urban community in Accra, Ghana. Int.J.Curr.Res.Aca.Rev. 4(3): 197-209. doi: http://dx.doi.org/10.20546/ijcrar.2016.403.022 